\title{
Oral Squamous Cell Carcinoma Clinical Aspects
}

\author{
Nicolás Bolesina, Fabián L. Femopase, \\ Silvia A. López de Blanc, Rosana A. Morelatto and María Alicia Olmos \\ Universidad Nacional de Córdoba, Córdoba \\ Argentina
}

\section{Introduction}

Oral cancer (OC) is considered a serious public health problem that causes great morbidity and mortality in the population. While OC has a lower incidence than other malignant tumors, it is known to produce high mortality and serious disturbances or discomfort in the patient as a consequence of either the tumor itself or of the treatment. The Oral Squamous Cell Carcinoma is the most common malignant tumor of the lip, oral cavity and oropharynx ( $90 \%$ of the cases) while the remaining $10 \%$ of the cases are mainly melanomas, sarcomas, minor salivary gland carcinomas and metastatic cancers (Scully et al., 2006).

In this chapter the attention is focused on the clinical characteristics of OSCCs.

Topics: Clinical presentation, Symptoms, Diagnosis, Prognosis, Oral and Dental Management and Psychological aspects of patient care.

\section{Clinical presentation. Symptoms}

Oral Squamous Cell Carcinoma (OSCC) presents different clinical aspects which are related with the location of the tumor, evolution time, precancerous lesions and risk factors. The most frequent clinical aspects are: tumor, ulcer, vegetans, verrucous and mixed forms such as ulcerous-vegetans or verrucose- ulcers (Boring et al., 1994).

The diagnosis of early lesions such as in-situ or microinvasive carcinoma, represents a real challenge for health professionals. Leukoplakia, erythroplakia or erythroleukoplakia are the most frequent clinical aspects, which may present superficially eroded areas. Chorion infiltration may be suspected when increased consistency on palpation is observed. The abovementioned lesions are asymptomatic, tend to keep their size, may show changes in the surface and do not respond to local treatments. The lesion can progress and develop as an exophytic, irregular lobulated lesion or adopt an endophytic growth pattern characterized by a depressed ulcer with grayish-white edges, elevated, everted and indurate borders and an infiltrated base. In most cases, lesions are asymptomatic; pain appears only when muscles or nerves are invaded at advanced stages of the disease. (Neville et al., 2002; Silverman et al., 1998) 
According to different authors, the lip is the most common location of OSCCs. In such cases, patients are likely to consult a physician or a dermatologist while in cases of tongue tumors, consultation to the dentist is more frequent. The paramedial area of the inferior lip is the most often region affected by lip cancer whereas the most prevalent precancerous lesions are actinic chronic cheilitis. OSCCs most common clinic manifestations are the loss of superficial tissue, erosion, ulcers (Fig.1) and occasionally exophytic shaped lesions: keratotic, verrucous or vegetant, with tumorous or "skin horn" aspect (Neville et al., 2002; Silverman et al., 1998). Chronic exposure to the sun produces in affected patients an alteration of the shape of the lip called lip everted or "lip on balcony".

A significant atrophy of the vermillion area with scales that do not tend to shed and therefore accumulate to form keratosis can often be observed. This type of lesions alternate with white lesions and erythro-leukoplakia areas that are prone to cracking, erosion or ulceration which are called actinic cheilitis. Lip cancer develops slowly and in advanced stages it can extend to the corner of the mouth or to the gingiva. It can also develop metastatic lymph nodes in submental and submandibular areas (Grinspan, 1983).

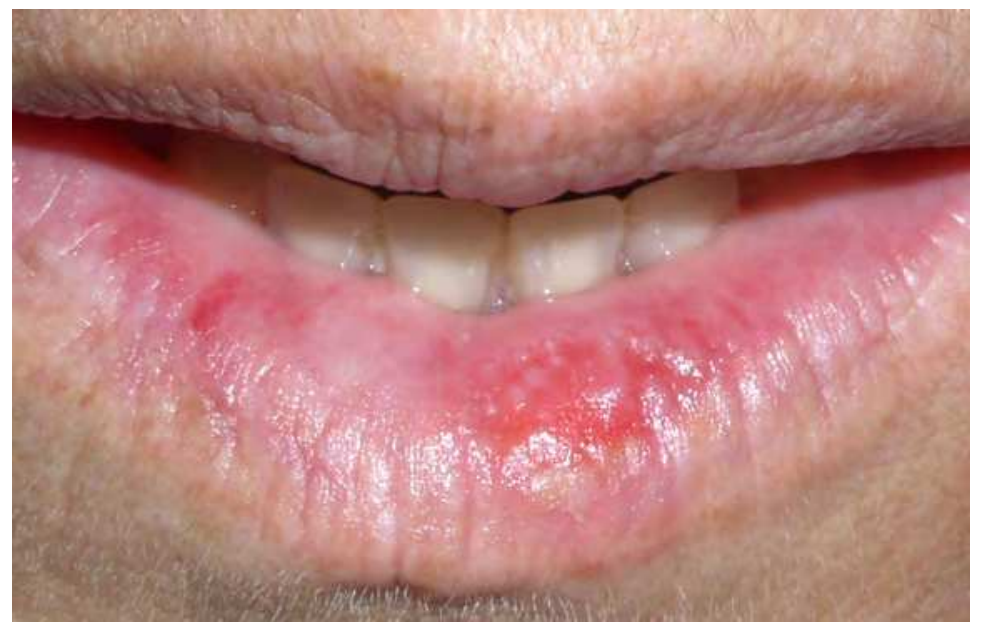

Fig. 1. In-situ carcinoma of the lower lip vermillion

Tongue carcinoma is the most commonly observed OC into the oral cavity; traumatic lesions, leukoplakia and lichen planus are predominant precancerous conditions. Tongue carcinoma represents $30-40 \%$ of OCs, the lateral tongue being the most frequent situation (80\%), followed by ventral and dorsum (Brandizzi et al., 2008).

Lateral border of the tongue and ventral surface OCs are usually preceded by traumatic lesions caused by sharp cusps or sharp edged teeth, by badly positioned teeth or by maladjusted dentures that chronically rub the mentioned areas. Ulcerated forms are the most frequently observed, see Fig 2, followed by exophitic tumor, which generally produce pain irradiating to the ear. In the ventral area, ulcer-vegetant or mixed forms predominate. Tumors on the dorsum are generally associated to lichen planus or to leukoplakia lesions. They are clinically observable as ulcerated forms tend to expand on the surface rather than go deeper into it. The lateral border of the tongue and the floor of the mouth (with 
extensions to the back lateral soft palate and tonsillar areas) combine to form a horse shoeshaped region in the oral mucosa that was described by Jovanovic et al., (1993) as highly risky for cancer development and also as a bad prognostic area.

These tumors tend to evolve towards the ventral side and to the floor of the mouth. In the first consultation, $40 \%$ of the patients have lymph nodes. When the lesion has more than 4 $\mathrm{cm}$, lymph nodes are present in $90 \%$ of the cases (Grinspan et al., 1983). Tumors located in the anterior half of the tongue usually lead to lymphadenopathy in the suprahyoid region while those located in the posterior half lead to submaxillary, carotid and lateropharyngeal nodes. Contralateral nodes are more frequent from tumors in the ventral surface and floor of the mouth (Shah et al., 1990; Grinspan, 1983).

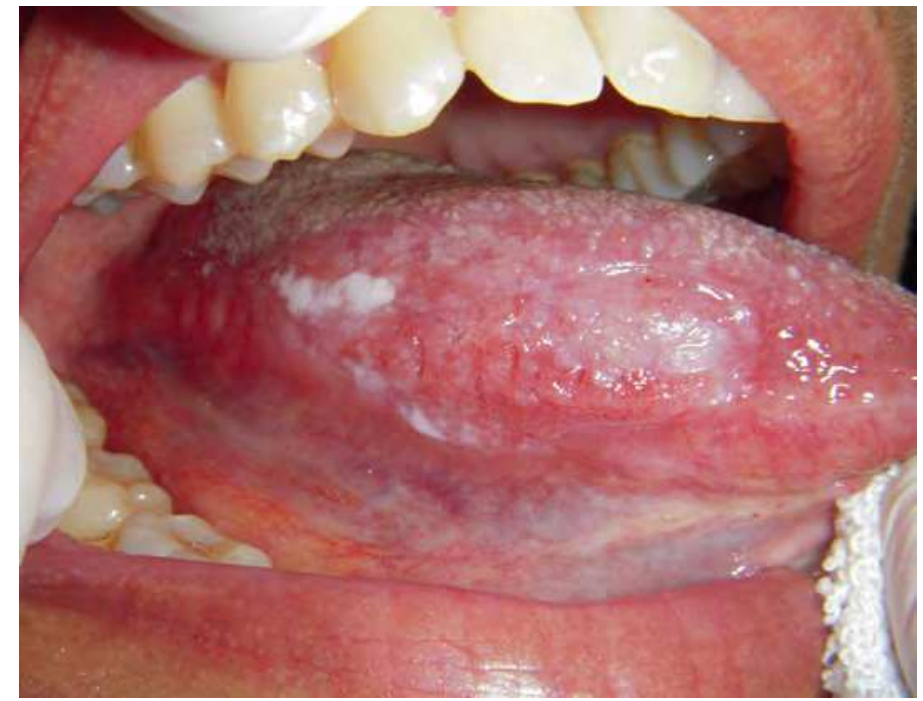

Fig. 2. Tongue infiltrant SCC, T2 N1 Mo

According to our experience in Argentina, OSCCs in gum and alveolar ridge are the 2nd most frequent locations (Brandizzi et al., 2008.) which is not the case in other countries (Boudewijn et al., 2009, Chandu et al., 2005). It is difficult to detect previous lesions when the carcinoma is located in the gingival or alveolar ridge. In such locations, however, it is common to associate them with periodontal disease.

Chronic inflammatory processes would release genotoxic mediators that would stimulate the accumulation of genetic defects leading to the appearance of malignant cells. In its initial stage, gingival carcinoma looks like a red or/and white spot slightly vegetant, extending on the surface due to the resistance offered by the periosteum (Fig 3). As OSCC advances, it adopts a tumoral shape, it may invade the bones, produce loosening of teeth and cause pain or trismus. Its progress through the lymph affects the submental, submandibular and carotid regions, these ones becoming the most common bilateral metastases. The antero inferior lesions progress towards the floor of the mouth and to the ventral side of the tongue. If the tumor is located in the posterior zone, it invades the floor of the mouth as well as the masticatory muscles. 


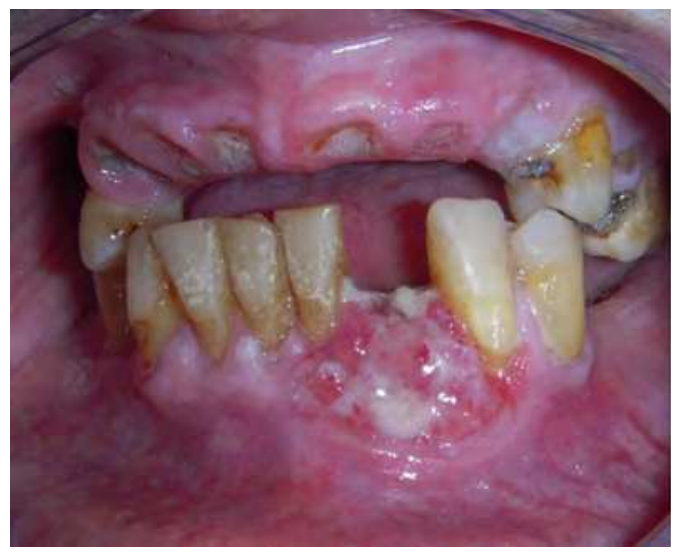

Fig. 3. Gum carcinoma, the tooth was lost due to bone tumor invasion

The floor of the mouth OSCC starts mainly in the anterior area as red and/or white spots, plaque or nodular, ulcerated lesions, later indurated at palpation (Fig. 4). It is not painful at an early stage although the tongue's mobility can eventually be impaired. It advances from the surface to the depths of the tissues, invading the floor of the mouth muscles, the submental, submaxillary and cervical nodes.

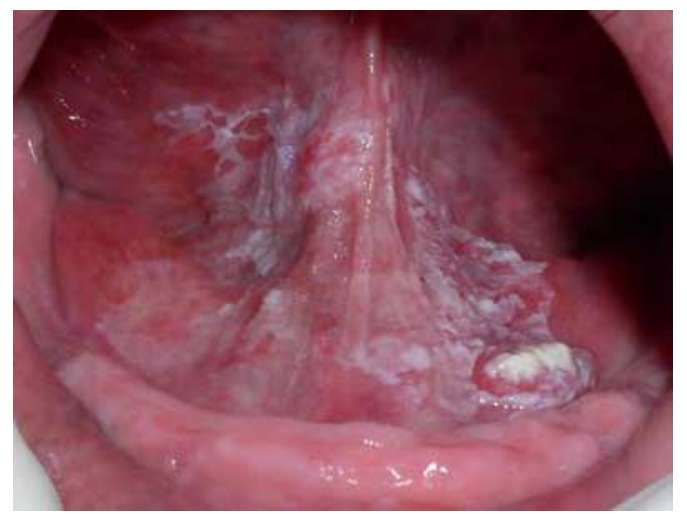

Fig. 4. Floor of the mouth, infiltrant SCC, two foci born in a leukoplakia

Most buccal mucosa SCC is characterized by developing on previous lesions. The leukoplasiform and erythroplastic forms are commonly observed in the anterior part of the buccal mucosa while in the posterior one it is more often secondary to traumatic lesions or lichen planus. One of the first signs of the transformation is the induration of erythoplastic lesions that tend to develop an exophytic aspect as they grow (Fig. 5). This type of SCC rarely presents ulcers whereas differentiated histopathologic forms are predominant. When SCC appears in the posterior third of the buccal mucosa, it usually presents itself as endophytic or ulcers; undifferentiated histological types is the most frequent that have a worse prognosis than in the anterior third. The affected nodes are generally situated in the submaxillary area and less frequently in the cervical or facial ones (Grinspan, 1983; Jovanovic et al., 1993). 


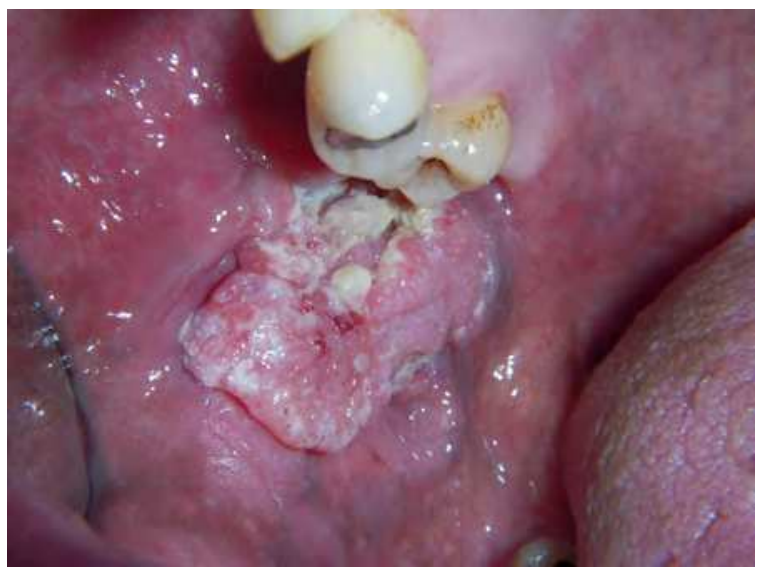

Fig. 5. OSCC of the buccal mucosa, an exophytic aspect.

When we analized the habits associated to OSCC location, we observed that $85 \%-90 \%$ of the patients affected with floor of the mouth and oropharygeal carcinoma were smokers and drinkers. Fewer than $40 \%$ of those with gum and tongue carcinoma had both habits (Fig. 6).

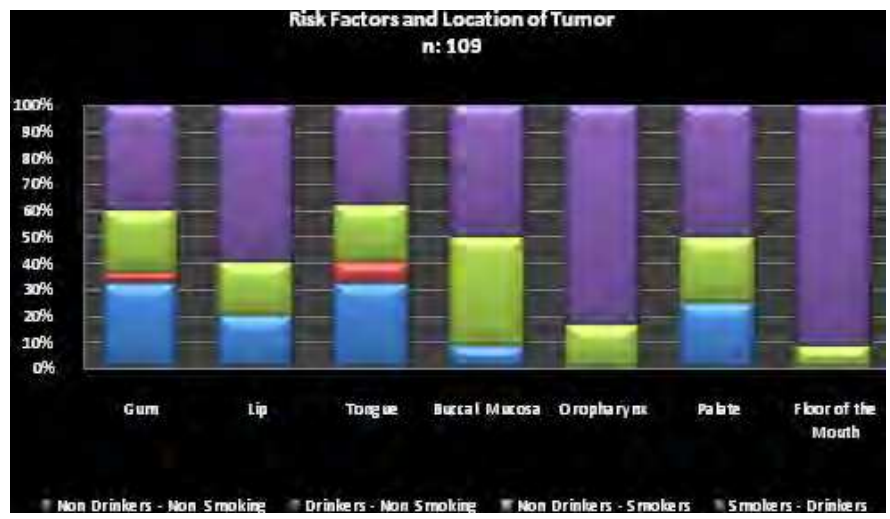

Fig. 6. Risk factors and location of the tumor

To highlight: It is essential for everyone to undergo a proper oral examination. Pain in itself is not a reliable indicator of malignancy; in many of the studied cases, early lesions were associated with only minor discomfort.

\subsection{Lymph nodes}

According to the natural history of OSCCs, invasive lesions would lead to their spreading through the lymph nodes. Mobile, painless nodes whose volumes increase in course of time, and fix to surrounding tissue in the advanced stages, are those clinically suggestive of malignancy. 
Union for International Cancer Control (UICC) recommended to classify the location of lymph nodes in the following levels:

Level I: submandibular and submaxillary nodes.

Level II: upper jugular nodes.

Level III: jugular media.

Level IV: lower jugular.

Level V: nodes in the posterior triangle, bounded at the back by the anterior border of the trapezius muscle, anteriorly by the posterior border of the sternocleidomastoid and below by the clavicle. Descriptive purposes can be divided into high, medium and low by two horizontal planes: the superior plane is situated below the hyoid bone and the inferior one in the lower edge of the cricoid cartilage.

Level VI: lymph nodes in the central compartment, which extends from the suprasternal notch to the hyoid bone. Lateral boundaries are formed on each side by the body's internal carotid sheath.

Level VII: lymph nodes located in the upper mediastinum, below the suprasternal notch.

\subsection{TNM system and staging}

According to the literature, the first classification of malignant tumors is Pierre Denoix's (1944) Tumor Node Metastasis (TNM), based on the extent of primary tumor (T), involvement of regional lymph nodes $(\mathbf{N})$ and metastasis at distance $(\mathbf{M})$. Such classification also applies to OSCCs of the mouth. Proper classification and staging allows the physician to determine treatment more appropriately, evaluate results of management more reliably and compare worldwide statistics reported from various institutions.

Currently, the American Joint Committee on Cancer (AJCC) and the UICC periodically update cancer staging, which is used by physicians and health care professionals throughout the world to facilitate the uniform description of neoplastic diseases. UICC rules to classify tumors are:

- The classification applies only to carcinomas in the lip vermilion, in the oral cavity, pharynx, larynx, sinuses mucous including minor salivary gland tumors.

- There should be histological confirmation. When the histology comes from another institution, it is recommended to have it reviewed by the pathologist in the working team.

- The extent of the disease should be evaluated by clinical examination, endoscopy and imaging.

In patients with advanced OSCC plus a history of heavy smoking, chest Computer Tomography (CT) is recommended before deciding on treatment because of the considerable possibility of undetected metastases in previous X-Ray tests.

The staging of each case must be determined before treatment and should not be changed whatever findings emerge after starting it. You can add such findings but you cannot change the staging. If doubts arise concerning it, assigning the patient the lowest category is the most convenient procedure.

Tables 1 shows the TNM classification and Table 2 describes the staging. 


\begin{tabular}{|c|c|c|}
\hline $\mathbf{T}$ & $\mathbf{N}$ & $\mathbf{M}$ \\
\hline Tumor & Nodule & Metastasis \\
\hline Tis: in situ Carcinoma & $\begin{array}{l}\text { N0: nonpalpable regional } \\
\text { lymph node }\end{array}$ & $\begin{array}{l}\text { M0: No distant } \\
\text { metastasis }\end{array}$ \\
\hline $\mathrm{T} 1:<2 \mathrm{~cm}$. diameter & $\begin{array}{l}\text { N1: ipsilateral single } \leq 3 \mathrm{~cm} \\
\text { palpable nodes }\end{array}$ & $\begin{array}{l}\text { M1: clinical or } \\
\text { radiographic evidence } \\
\text { of metastasis }\end{array}$ \\
\hline T2: 2 to $4 \mathrm{~cm}$. diameter & $\begin{array}{l}\text { N2: ipsilateral or contralateral } \\
\text { palpable lymph nodes } \\
3 \text { to } 6 \mathrm{~cm} \text {. subdivided into: } \\
\text { N2a: an ipsilateral single node } \\
3 \text { to } 6 \mathrm{~cm} \text {. } \\
\mathrm{N} 2 \mathrm{~b} \text { : ipsilateral multiple } \\
\leq 6 \mathrm{~cm} \text {. } \\
\text { N2c: contralateral or } \\
\text { bilateral } \leq 6 \mathrm{~cm} \text {. }\end{array}$ & \\
\hline $\begin{array}{l}\text { T3: Tumor }>4 \mathrm{~cm} \text {. diameter } \\
\text { T4: invaded adjacent tissues } \\
\text { T4a: moderately advanced local } \\
\text { disease } \\
\text { T4b: very advanced local disease }\end{array}$ & N3: $>6 \mathrm{~cm}$. & \\
\hline
\end{tabular}

Table 1. TNM Classification of malignant Tumors

\begin{tabular}{|c|c|c|c|}
\hline Stage & Tumor & Node * & Metastasis \\
\hline Stage 0 & Tis & N0 & M0 \\
\hline Stage I & T1 & N0 & M0 \\
\hline Stage II & $\mathrm{T} 2$ & N0 & M0 \\
\hline \multirow{4}{*}{ Stage III } & $\mathrm{T} 1$ & N1 & M0 \\
\hline & $\mathrm{T} 2$ & N1 & M0 \\
\hline & $\mathrm{T} 3$ & No & M0 \\
\hline & T3 & N1 & M0 \\
\hline \multirow{6}{*}{$\begin{array}{l}\text { Stage IVA } \\
\text { moderately advanced } \\
\text { local/ regional } \\
\text { disease }\end{array}$} & $\mathrm{T} 4 \mathrm{a}$ & N0 & M0 \\
\hline & $\mathrm{T} 4 \mathrm{a}$ & N1 & M0 \\
\hline & $\mathrm{T} 1$ & N2 & M0 \\
\hline & $\mathrm{T} 2$ & N2 & M0 \\
\hline & T3 & N2 & M0 \\
\hline & $\mathrm{T} 4 \mathrm{a}$ & $\mathrm{N} 2$ & M0 \\
\hline $\begin{array}{l}\text { Stage IVB } \\
\text { very advanced } \\
\text { local/regional disease }\end{array}$ & $\mathrm{T} 4 \mathrm{~b}$ & Any N & M0 \\
\hline \multirow{2}{*}{$\begin{array}{l}\text { Stage IVC distant } \\
\text { metastatic disease }\end{array}$} & Any $\mathrm{T}$ & N3 & M0 \\
\hline & Any $\mathrm{T}$ & Any N & M1 \\
\hline
\end{tabular}

* Extracapsular spread (ECS) of disease is added as ECS + or ECS - as a descriptor.

These descriptors will not influence nodal staging.

Table 2. Stage grouping for oral cavity, oropharyngeal, hypopharyngeal and laryngeal cancers from UICC: TNM Classification of Malignant Tumours 


\section{Variables that influence diagnosis}

\subsection{Diagnostic delay}

Oral cancer is a global health problem of increasing incidence and mortality rates; more than 500,000 patients worldwide are estimated to have oral cancer (Parkin et al., 2005). The International Association for Cancer Research (IARC) and the World Health Organization (WHO) latest records show an incidence of 263,020 cases (3.8 rate) with high mortality 127,654 (1.9 rate ), (Ferlay et al., 2010).

Unfortunately, the 5-year survival rate has not changed during the last half of the century, still being around $50-55 \%$ in spite of the advances in diagnosis and treatment (Neville and Day, 2002). Early diagnosis is a foremost step for reducing cancer mortality (Boyle et al., 2003), since the identification of smaller lesions allows less aggressive and debilitating treatments. However, almost half of intraoral cancers have late diagnosis (stages III or IV).

Diagnostic delay is, therefore, the main reason why most patients' OSCCs are discovered in advanced stages when their diagnoses are finally made. Late diagnosis is the result of either patient or professional delay (Kerdpon \& Sriplung, 2001, Rogers et al., 2007).

There is a vast literature about the results of research on this interesting topic carried out in populations from all over the world (Table 5).

We investigated OSCC diagnosis delay in Córdoba in a retrospective study of clinical records of OSCC patients, examined in the Stomatology B service (a referral clinic for oral soft-tissue lesions) and in the Oncohematology Unit of Hospital Nacional de Clínicas (Morelatto et al., 2007). We included in that study patients diagnosed with OSCC as their first cancer between 1992 and 2004. Oral exams and diagnosis at both centers were made by the same trained professionals and supervised by the same head professor. Age, sex and location of the OSCC, first signs or symptoms, and first consultation with a health professional (HP) were studied. Stage at the moment of the diagnosis was classified according to the 1997 version of the UICC, AJCC. The symptoms were classified as pain, swelling, ulceration, white lesions, poor denture fit and others. Stages III and IV (S III and S IV) were defined as advanced tumors and S I and S II as early ones (Brohua et al., 2005).

In order to study the OSCC diagnostic delay, the authors described the following categories:

A- Patient delay: considers the time elapsed between the first sign or symptom noticed by the patient and the first consultation with a HP. B- Professional delay: considers the period of time between the first consultation with a HP and the referral to the specialist who performed the biopsy (Kerdpon \& Sriplung, 2001). C- Patient and professional delay: considers the period of time between the final diagnosis and the beginning of treatment (Kowalski \& Carvalho, 2001).

A lapse of more than 30 days in any category (A, B or C) was regarded as delay (Shah \& Lydiatt, 1995). The data aforementioned were statistically analyzed.

In our study, $68 \%$ of the patients in the early stage and $54 \%$ in the advanced stage evidenced patient delay (see Table 3). On the other hand, $72 \%$ of the patients in the early stage and $61 \%$ 
in the advanced stage had a professional delay of more than 30 days (Table 4). In both cases, the delay was more pronounced in early stages.

\begin{tabular}{cccccc}
\hline Delay A & $\begin{array}{c}<30 \text { days } \\
\mathrm{n}(\%)\end{array}$ & $\begin{array}{c}30-60 \text { days } \\
\mathrm{n}(\%)\end{array}$ & $\begin{array}{c}60-120 \\
\text { days } \\
\mathrm{n}(\%)\end{array}$ & $\begin{array}{c}>120 \text { days } \\
\mathrm{n}(\%)\end{array}$ & $\begin{array}{c}\text { Total delay } \\
\mathrm{n}(\%)\end{array}$ \\
S I and II & $6(32)$ & $2(10)$ & $3(16)$ & $8(42)$ & $13(68)$ \\
S III and IV & $23(46)$ & $12(24)$ & $8(16)$ & $7(14)$ & $27(54)^{*}$ \\
Total & $29(42)$ & $14(20)$ & $11(16)$ & $15(21)$ & $40(58)$ \\
\hline
\end{tabular}

*In one patient, delay A was unknown.

Table 3. Patient delay (A) related to the stage of the tumor.

\begin{tabular}{|c|c|c|c|c|c|}
\hline Delay B & $\begin{array}{c}<30 \text { days } \\
\mathrm{n}(\%)\end{array}$ & $\begin{array}{c}30-60 \\
\text { days } \\
\mathrm{n}(\%)\end{array}$ & $\begin{array}{c}60-120 \text { days } \\
\mathrm{n}(\%)\end{array}$ & $\begin{array}{c}>120 \text { days } \\
\mathrm{n}(\%)\end{array}$ & $\begin{array}{c}\text { Total delay } \\
\mathrm{n}(\%)\end{array}$ \\
\hline S I y II* & $5(28)$ & $4(22)$ & - & $9(50)$ & $13(72)^{*}$ \\
\hline S III y IV & $20(39)$ & $6(12)$ & $18(35)$ & $7(14)$ & $31(61)$ \\
\hline Total & $25(36)$ & $10(14)$ & $18(26)$ & $16(23)$ & $44(64)$ \\
\hline
\end{tabular}

* In one patient, delay B was unknown.

Table 4. Professional delay (B) related to the stage of the tumor

A similar finding was reported in Greece and in the Netherlands with $52 \%$ of patients with more than 3 weeks ( Pitiphat et al., 2002) and 46 days of delay, respectively ( Jovanovic et al.,1992). A median time of 3 months or more until diagnosis was described for Canada (Elwood \& Gallagher, 1985), Italy (Mashberg et al., 1989), Finland (Soderholm, 1990), Denmark (Wildt et al., 1995) and Israel (Gorsky \&Dayan, 1995). Although the results obtained in Argentina were more optimistic than in those of some other populations, the proportion of patients who had delayed diagnosis was still considerably high. The mean time between the first symptom and the consultation with a HP (delay A) was 2.5 months in females and 2.3 in males. The percentage of delay A of more than 1 month (68\%) in Córdoba is similar to the value found by Jovanovic et al., $1992(53.7 \%)$ and lower than results obtained by Pinholt et al., 1997, (92\%).

It should be considered that there are some limitations in the present research namely, that many patients did not exactly recall the onset of their symptoms (Wildt et al., 1995). Pain was the most common first symptom, but more than half of the patients did not visit a medical facility to receive treatment before one month following that occurrence. Onizawa et al., 2003 consider that the symptom may not be bothersome or severe enough to seek professional help. 
The time elapsed between the first symptom and its diagnosis was longer for women than for men in our population (77.5 and 67.8 days respectively); Wildt et al., 1995, reported similar results. In our research, we observed that $100 \%$ of lip cancers and $38 \%$ of tongue lesions were staged as early cancers at the time of diagnosis, while Gorsky \& Dayan, 1995 in Israel found $82 \%$ in lip and $58 \%$ of tongue tumors in that stage. According to our research professional delay (B) was the most related variable to the stage of the tumor at the time of diagnosis. As shown in Table 4, B was more important in early stages; this observation is relevant because treatment delay worsens the prognosis.

\begin{tabular}{|l|lll|}
\hline Country & Author / Year & $\mathrm{N}$ & Delay \\
\hline The Netherlands & Jovanovic et al., 1992 & 50 & patient \\
Australia & Dimitroulis et al., 1992 & 51 & patient \\
Brazil & Kowalski et al.,1994 & 336 & professional \\
Israel & Gorsky et al., 1995 & 543 & professional \\
\hline Denmark & Wildt et al., 1995 & 167 & patient \\
\hline Malaysia & Khoo et al., 1998 & 65 & Patient and \\
\hline Canada & Allison et al., 1998 & 188 & professional \\
\hline Thailand & Kerdpon et al., 2001 & 161 & patient and \\
\hline Japan & Onizawa et al., 2003 & 152 & professional \\
The Netherlands & Tromp et al., 2005 & 306 & patient \\
\hline Ireland & O'Sullivan et al., 2005 & 370 & patient \\
Netherlands & Brouha et al., 2007 & 173 & professional
\end{tabular}

Table 5. Responsibility of diagnostic delay in oral cancer in different countries according to several authors

OSCC diagnostic delay has been thoroughly studied and its causes seem to be always the same: (i) unawareness of most of the population regarding the potential malignancy of oral lesions (patients' delay), (ii) inaccurate diagnosis on the part of the HP and (iii) delay in referral for treatment (Allison et al., 1998; Dimitroulis et al., 1992), see Table 5.

Medical practitioners usually prescribe various medications; it is more common, however, that dentists adopt a more mechanical approach such as extracting teeth or adjusting dentures (Kerdpon \& Sriplung, 2001). Both tend to be slow in suspecting malignancy.

The findings of the present study also indicate that patients are partially responsible for delay in OSCC diagnosis.

\subsection{Awareness}

Due to the apparent lack of awareness of patients suffering from OSCC assisted by different services in various countries, we studied the general public in Cordoba City to assess levels 
of awareness and knowledge of oral cancer, risk factors, suspicious clinical signs and parameters related to early consultation to HP (Robledo et al., 2008). Anonymous surveys were carried out, obtaining a systematic sampling from the 2004-2005 telephone directory of Cordoba City. Four hundred effective surveys were made to Argentine citizens older than 18. Results: $41 \%$ of the participants did not know of the existence of OC, the highest percentage of poor or no information was found among people younger than 30 years of age. Only $60 \%$ of those who knew about OC were able to name a risk factor, being tobacco the most easily associated. It is surprising that only $3 \%$ of the questioned people associated alcohol, related tobacco-alcohol consumption or unadjusted dentures as risk factors. Only $45 \%$ had some knowledge about clinical manifestations, pain and ulcers being the most frequently mentioned. Though most of the surveyed population had consulted a dentist one or several times a year, only $32 \%$ could recall if they had had a comprehensive oral exam. Evidently, the population badly needs to be informed about risk factors and first clinical manifestations of OC and about the importance of early consultation.

In a study of Humphris et al. (2004), a randomized controlled trial found that patients attending primary care who had read an information leaflet about head and neck cancer had increased awareness of risk compared to patients who had not seen the leaflet. A questionnaire of awareness of signs and symptoms and risks of oral cancer showed that all those who received the leaflet (smokers, non-smokers and past smokers) reported greater knowledge $(p<0.001)$. Smokers were 16 times more likely to perceive that they were at greater risk.

It would also be highly necessary to have access to professionals with further training in the detection of precancerous lesions and OC early signs.

\section{Prognosis. Survival rate}

Cancers of the oral cavity have a high mortality rate and, despite the current progress in treatments, the situation has not improved. A five-year survival rate ranging from $30 \%$ to $80 \%$ has been reported from several parts of the world. Survival rates are lower in developing countries (Sargeran et al. 2008). We made a research on that subject in Córdoba in an retrospective study of 89 clinical records of OSCC patients, followed in the Stomatology B Service and in the Oncology Unit of Hospital Nacional de Clínicas between 1989-2005, (Bolesina et al., 2007). Survival rates were related to age, gender, location, stage, risk factors and treatment; $74 \%$ of the patients were male, age range was $23-93$, median age 60 years. The lowest survival rate was found between 61 and 70 years of age. After five years of OSCC diagnosis, the general survival rate reached $35-40 \%$. The most frequent cancer location was in the tongue $(26 \%)$, followed by gum $(23 \%)$ and floor of the mouth $(11 \%)$. The highest mortality rate was due to tumors situated in the base of the tongue, gum and floor of the mouth, $100 \%, 88 \%$ and $85 \%$, respectively. It was noted that $100 \%$ base of the tongue tumors , $90 \%$ gingiva and floor of the mouth tumors were discovered in advanced stages while $100 \%$ of lip tumors were diagnosed in early stages.

The observed survival rate in OSCC stage I was $75 \%$ whereas only $23 \%$ patients survived in stage IV. When all the variables were analysed and related to survival rates, a value of $\mathrm{p}=$ 0.001 was obtained for tumor stages (Fig. 7). 


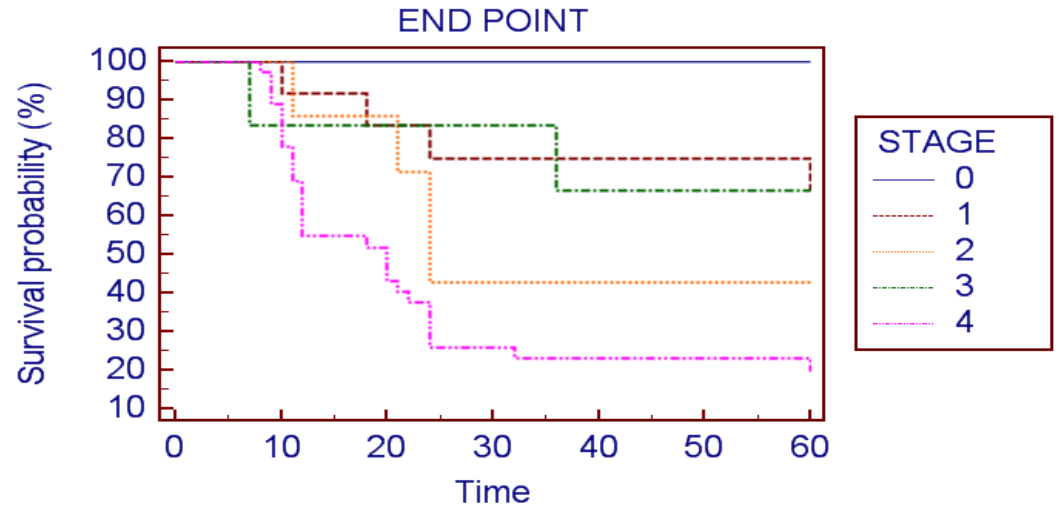

Fig. 7. Five year survival rates, according to OSCC stage at the moment of diagnosis

When surgery was the only treatment indicated, patient survival rate was $55 \%$. When radiotherapy complemented surgery, the rate decreased to $33 \%$, which is in good agreement with the literature (Sargeran et al., 2008).

As far as risk factors are concerned, it has to be pointed out that $49 \%$ of the patients were smokers and heavy drinkers; higher mortality rates were found specially in male patients having these habits compared to those with only one or none of them. The $p$ value obtained for alcohol consumers and tobacco smokers was 0.04 , see Fig 8.

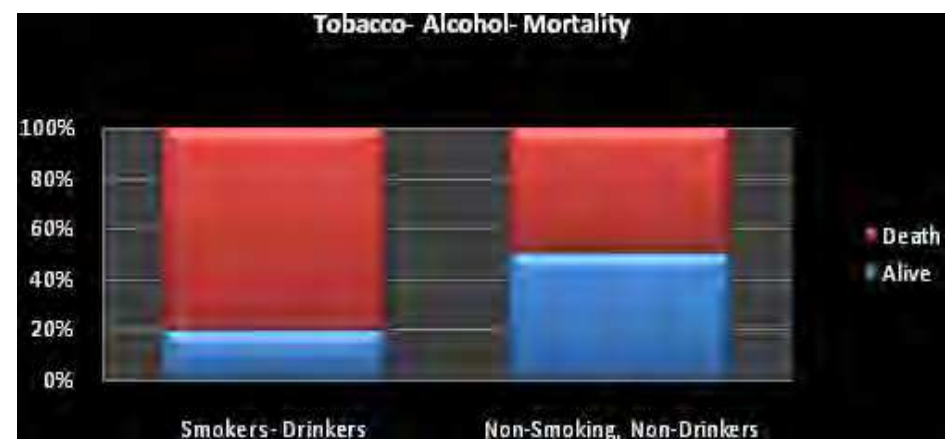

Fig. 8. Percentaje of patients who died before 5 years, related to risk factors

In our study, we did not have a significant enough sample of young patients to reach definitive conclusions. However, previous studies show that younger people have a considerably better five-year survival. Age is therefore a determining factor to good outcomes for OSCC patients (Warnakulasurilya et al. 2007). Although it is well known that tobacco smoking and alcohol consumption are the strongest risk factors for the development of head and neck cancer, little information is available concerning both the prognostic value of these habits and that of quitting them after diagnosis. 
Non-smokers with early stage OSCC have a better prognosis than former or current smokers at the same stage (Vora et al., 2003), which agrees with the results obtained in our study.

Smoking cessation after diagnosis or starting OC therapy can improve survival rates. It is reported that head and neck cancer patients who admitted to continuing smoking during their radiotherapy treatment had a lower response and survival prospects than those who claimed to quit smoking prior to starting the treatment, with 2.5 RR (95\% CI 1.4-4.4) (Browman et al., 1993). RR of recurrence of the disease among smokers (non drinkers) was 2.9 compared to non/ex-smokers and 3.8 for those smoking $>2$ packets a day (Stevens et al., 1983). In a retrospective study in Southern England, RR for multiple primary cancers was higher in those patients who continued smoking and drinking after therapy (Warnakulasuriya et al., 2003).

To sum up, these studies provide clear evidence that smoking cessation even after an oral cancer diagnosis improves prognostic outcomes. Oral cancer patients who were current drinkers showed higher mortality rates than former or non drinkers (Kowalski et al., 1994). Quitting drinking after diagnosis was also associated with improved survival outcomes, but the hazard ratios did not reach statistical significance.

The findings suggest that rising alcohol consumption since the 1950s is more closely related to increasing intra-oral cancer incidence and mortality than smoking, a fact that is more evident among younger males since the early 1970s (Hindle et al., 2000).

There are a myriad of risk factors that lead to OC, among them Human Papilloma Virus and other infections, chronic inflammations and social and environmental carcinogen conditions. These issues are the subject of continuous studies being carried on at present by several scientific teams.

\section{Patient management}

The decision about the adequate treatment for each patient should be made by an interdisciplinary committee of specialists in head and neck tumors. The choice of treatment largely depends on the site and stage of the disease and on the overall health status of the patient. Early stages of intraoral cancers are likely to be cured by surgery or radiation therapy. The election of the type of treatment is determined by the anticipated functional and cosmetic results and by the availability of the particular expertise required from the surgeon or radiation therapist for each patient. Advanced tumors (stages III and IV) are generally treated by surgery, followed by radiation therapy.

The treatment for head and neck cancers, especially those involving the oral cavity, has changed in the last 10-20 years. It is now widely accepted that for advanced OC tumors, surgery combined with radiation therapy has a better outcome than if only one of those modalities is used. Although the impact of neo-adjuvant chemoradiation may increase survival, it may also increase morbidity considerably.

It is worth mentioning that current advent of state-of-the-art technology applied to cancer treatments has significantly improved the quality of life of OC patients. However, there are only few data as to the length of survival in relation to new devices such as gamma rays, electrons, protons and atomic nuclei, tridimensional (3DR), stereotactic, Modulated Intensity Radiotherapy (MIR) and Image-Guided Radiation Therapy (IGRT). The new technology 
allows the professional to better adjust radiation to the tumor, thus diminishing the damage inflicted to the surrounding healthy tissues, especially major salivary glands and maxillaries. Brachytheraphy is a still used resource; it requires the isolation of the radiated patient and it should be carried out by highly experienced professionals.

In spite of all the above mentioned innovations, the occurrence of complications is high, which would inevitably delay the standard therapeutic protocols. This fact, in turn, would make patients prone to recurrence or to metastases.

\subsection{More frequent oral complications}

All treatments usually applied to deal with OSCC and also with head and neck cancers have a negative impact on the patients, especially on their oral cavity; several complications can arise due to direct damage to oral tissues or to indirect regional or systemic toxicity. What is more, dental care is regarded by many patients as a low priority in their treatment. Surprisingly, $90 \%$ of the treated patients were found to have dental diseases such as caries, periodontal diseases or sepsis (Toljanic et al., 2002). The factors that influence intensity and duration of oral damage are: the medical and nutritional status of the patient, tobacco and alcohol use, oral hygiene and dental status, previous surgical interventions, and the indicated radiation treatment.

\subsubsection{Surgical risks and complications}

Surgical management of intraoral lesions typically includes both the primary lesion and cervical lymph nodes. Ideally, surgery is selected when permanent control of the tumor is sought. The tumour staging is essential to determine whether only surgery is indicated or whether radiation or chemotherapy may be needed later.

The risks and sequels of surgery primarily depend on or develop from the extent of the tumor and its relationship to contiguous oral structures. Sequels may include disorders in speech and swallowing, pain, limitations in oral motor function; infections, enteral nutrition (e.g. tube feedings), facial, neck and shoulder malfunction, disturbances in mental health, fibrosis, cosmetic deficits and bone lesions.

During resection of oral cancers, teeth and their supporting bone are often removed. In order to achieve functional rehabilitation, it is necessary to replace missing elements. Some patients may require an intraoral prosthesis for obturation of a velopharyngeal deficit or to reshape and augment the contours of a resected hard palate. The work of a speech therapist is crucial in this venture (Vendrell \& Ranking, 1999).

\subsubsection{Potential oral manifestations of radiation therapy}

Patients that receive radiation therapy in the oropharyngeal area for malignant tumors may undergo radiation therapy for 7 weeks with a dose going up to 7000cGy, depending on tumor type and location. Radiotherapy is associated with side effects that vary in intensity and duration and are dependent on several factors. Not all patients will experience all possible complications but they should be aware of the potential risks.

Acute and chronic complications in the short and long term have been studied by different authors; some complications are described below. Hyposalivation during the 1st week of 
radiation treatment amounts to $50-60 \%$ of the usual saliva flow. After a 7 - week conventional treatment, it decreases to $20 \%$.

Hyposalivation subjective symptom xerostomy implies several other symptoms like dysphagia, dysgeusia, dysosmia and speach difficulties (Jansma et al., 1989).

Xerostomy brings about a change in oral microflora and, as a result, cariogenic microorganisms streptococos mutans y lactobacilos prevail in the saliva, causing caries and periodontal diseases. The oral mucosa becomes soft, irritable and susceptible of fungal infections (candidiasis) and inflammations (Daly \& Drane,1972; Hinds,1971).

Recently, preventive measures to decrease the effects of radiation induced xerostomy have been widely studied. To begin with, patients should give up tobacco, alcohol and spicy, too hot, too cold or too hard foods and replace them by soft and moist nutrients. Secondly, they should be advised to be well hydratated and to use saliva substitutes.

Salivary gland tissue does not recover from high doses of radiation. The quality and quantity of saliva is permanently changed. Taste loss and alterations may begin with the first 200-400 cGy. After three weeks of therapy, it takes 500-8,000 times normal concentrations of taste stimulant to elicit a normal taste response. Taste acuity levels usually return to normal within 2-12 months following completion of therapy, if adequate saliva is available (Jasma et al., 1989). Both mucositis and decreased salivary flow may contribute to taste alteration.

Mucositis: Oral mucositis is the inflammation that takes place in the oral epithelium as a result of antineoplastic treatments such as radiotherapy, chemotherapy or bone marrow transplant which are very frequent in these treatments for oncohematologic disease. Not only do the consequences of the inflammation affect the quality of life of the patient but it can also mean a limitation in the application of the treatment, as well as an increase in hospital length of stay and therapeutic costs.

Radiation-induced mucositis depends on the absorbed radiation dose, fractioning, delivery modality and soft tissue status. Other influential patient-related variables are age, sex, nutritional condition, oral microbiota, salivary flow and inflammation among others.

The study of the degrees of severity of oral mucositis has yielded different results coming from diverse research centers. This constitutes a major obstacle for the study of mucositis. The lack of a uniform systematic approach adopted for its evaluation by means of oral examination makes it difficult to assess its consequences.

The various existing scales to measure mucositis were analyzed by López Castaño et al., 2005; Stone et al., 2007; Sonis et al., 1999; World Health Organization, 1979 (see Table 6).

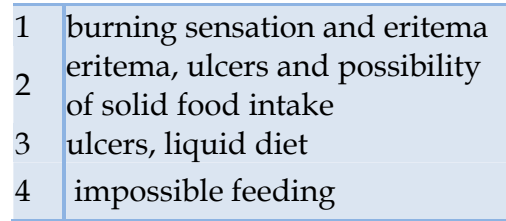

Table 6. Mucositis WHO Classification 
Oral Infections: Health care providers should be concerned about preventing oral local and systemic infections in addition to managing their symptoms. Treating infections as soon as they are detected will help to reduce pain, as well as control the spread of infection. A fungal, bacterial or viral culture is recommended if infection is suspected.

In patients undergoing head and neck radiotherapy, Candida colonization tends to increase during the course of the treatment and remains increased if xerostomia occurs (Epstein et al., 1998; Ramirez-Amador et al., 1997). Candidiasis can cause a burning or scalding sensation, can distort taste and may interfere with swallowing. Its spread to the esophagus or systemic dissemination is a serious consequence (Rankin \& Jones, 1999). Other opportunistic fungal infection is Histoplasmosis.

Bacterial and viral infections are more common in neutropenic patients than in those affected by oral cancers. The detection and treatment of those infections represent a challenge to health professionals and should be the subject of a more extensive study.

Nutritional deficiency: It is caused by the effects of mucositis, xerostomy, hypogeusia, and loss of appetite that can make eating an unpleasant painful chore, quite apart from the psychological implications that such discomforts may have on the eating function. Symptoms may include rapid weight loss, dehydration, nutritional stomatitis, and secondary oral infection, specifically candidiasis (Rankin \& Jones, 1999).

Caries: Even patients that have not suffered from dental caries for some time can develop them when submitted to radiotherapy. Those caries differ considerably in clinical appearance, development, and progression from dental caries in non-irradiated patients. Radiation has a pernicious effect on the teeth since it makes them prone to decalcification. Post-radiation lesions develop in a distinct manner with initial sheer fracture of enamel followed by rapid decay of the exposed underlying dentin (Jansma et al.,1993; Jongebloed et al., 1988). Such lesions are mainly developed when the flow of saliva diminishes or when its properties are altered (Brown et al., 1975; Carl \& Schaff, 1974). Furthermore, post- radiation lesions tend to occur at gingival margins, cusp tips, and incisal surfaces in contrast to typical caries, which develop in pits, fissures and proximal areas.

There are three kinds of radiation- related carious lesions:

First type: the lesion superficially covers the cervical tooth area, slowly progressing inwards until it often provokes the crown total destruction. This is less frequent in the molars, although the caries tend to appear on the surfaces of the whole molar area.

The second type of lesion is a generalized superficial defect that first affects the buccal and later the lingual or palatal surfaces of the tooth crowns. The proximal surfaces are less affected.This lesion often begins as a diffuse, punctate defect and then progresses to generalized, irregular erosion of the tooth surfaces. In this type of lesion, decay localized at the incisal or occlusal edges is often observed. The result is a destruction of the coronal enamel and dentin, especially on the buccal and palatal surfaces.

Third type: the lesion extends as a heavy brown-black discoloration over the whole set of tooth crown together with a marked wear of the oclusal and incisal sides (Vissink et al., 2003).The areas just below the contact points seem to be the last areas to be affected by radiation caries. 
Trismus and / or fibrosis: Spasms and/or fibrosis of the masticatory muscles and temporomandibular joint (TMJ) capsule, usually occurs 3-6 months after radiation therapy, with unpredictable frequency and severity. It is worsened by some surgical resections (Rankin \& Jones, 1999).

Limited opening may interfere with oral hygiene, dietary intake, use of prostheses and restricted access to dental care and general anesthesia (Barker et al., 1996).

It is often observed that floor of the mouth and neck fibrosis bears a relation with individual predisposing factors, among which peripheric circulatory disorders can be mentioned.

Soft tissue necrosis/osteoradionecrosis (ORN): Soft tissue and bone necrosis may develop because tissues within the field of radiation become hypovascular, hypoxic and hypocellular. The threat of this sequel persists indefinitely, although the risk is minimal when the total dose of radiation is < $5000 \mathrm{cGy}$.

The effects of radiation on bone, periosteum, connective tissue, and vascular epithelium generally develop over time and include suppressed osteoblastic activity, decreased cell numbers, disorganization of bone remodelling, hypovascularity and increased fibrosis. Smaller blood vessels are more sensitive than large vessels. Initially, there is a periarteritis and endarteritis that progress to fibrosis and loss of endothelium. This results in the narrowing and possible obliteration of the lumen, reducing the blood supply to all tissues within the radiation field.

Factors that may contribute to an increased risk of necrosis include compromised vascularity from previous surgery, poor nutritional or health status, uncontrolled diabetes and heavy tobacco or alcohol use. Trauma may result from tooth extraction, invasive periodontal procedures and intraoral prosthetic appliances. The necrosis process may take place spontaneously or result from trauma, leading to non-healing soft tissue, bone lesions, and necrosis. The mandible is much more susceptible to ORN than the maxilla. The incidence of ORN is twice as high in dentate patients as it is among edentulous patients.

Clinical manifestations of ORN may include pain, orofacial fistulas, exposed necrotic bone, pathologic fracture and suppuration (Barker et al., 1996).

The management of patients with ORN depends on the severity of the necrosis which may be controlled by local irrigation, antibiotic treatment, local sequestrectomy or wide segmental excision with or without reconstruction. Hyperbaric oxygen therapy is considered an adjunctive treatment for ORN, often used in conjunction with surgery, and has been associated with better success rates than surgery alone (Aitasalo et al., 1995; McKenzie et al., 1993).

\subsection{Oral and dental management}

\subsubsection{Pre oncologic treatment oral preparation}

With the increasing trend in outpatient management, including cancer therapies, every health care professional is a potential and integral part of the cancer treatment team that 
once existed solely within the hospital environment. To provide optimal therapy, a functional, communicative, interactive team is critical to the successful management and outcome of the cancer patient. This includes the evaluation and treatment planning considering the overall patient health, tumor site, stage and tumor biologic status and patient's cultural/socioeconomic status. Dentists, as part of a multidisciplinary team, have an active role before, during and after the treatment (Shaw, 1997).

The aims of oral care programs for OC patients are:

- $\quad$ to improve oral function and quality of life.

- to improve and keep oral hygiene so as to reduce risk and severity of oral complications.

- to eliminate oral infections and avoid tooth originated systemic ones.

- to prevent, eliminate or control oropharyngeal pain.

- to prevent or control salivary gland dysfunctions and tooth destruction.

- $\quad$ to prevent or reduce the incidence of bone necrosis.

The first step of the treatment should be a panoramic X-Ray in order to have a global vision. If tooth extractions are necessary for non-restorable or doubtful prognosis teeth (see criteria in Table 7), they should be made 15-20 days before radiation treatment and 5-10 days before chemotherapy.

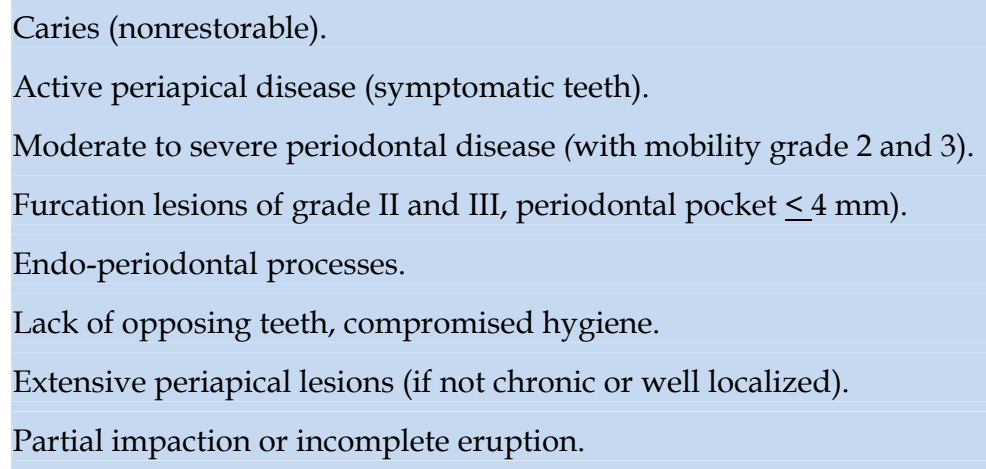

Table 7. Criteria for pre-radiotherapy extractions

Before starting radiotherapy, tissues must be healthy without tearing or leaks either in the oral mucosa or in the alveolar bones. Besides, endodontic treatment of deeply decayed teeth must be carried out, glass ionomer and resins must be used for cavity obturation, metallic reconstructions must be avoided, planing and polishing of the dental and prosthetic sharp cusps must be performed. There must be a tight control of microflora and of oral hygiene techniques. Fluoride tooth paste and adequate prothesis disinfection are highly advisable.

\subsubsection{During radiotherapy treatment}

A weekly check up by the interdisciplinary team will allow the professionals involved to detect early lesions and to make sure that the patient follows all preventive indications. 
Good results were obtained when a preventive program including mechanical and chemical biofilm control was put into practice.

\subsubsection{After a radiotherapy treatment}

Very strict oral hygiene as well as frequent visits to the dentist are mandatory to prevent infections and caries formation since extractions are highly unadvisable due to impending ORN risk.

It has become essential to implement specific training courses dealing with OC patient care, which should be progressively included in the grade curricula.

\section{Psychological aspects of patient care}

Oral cancer is a complex health problem that deeply affects the life of the patient since it involves vital body areas related to communication and emotions. Comparatively, it is even more disturbing than general cancer since head and neck cancer is clearly related to functional speech and swallowing problems; therefore, OC patients are among the most distressed sufferers.

We will point out here some of the characteristics of the patients given the painful experience they have to go through.

\subsection{Patient's previous history}

\subsubsection{Alexithymia}

It refers to a specific disturbance in psychic functioning characterized by difficulties in the capacity to verbalize affections and to elaborate fantasies. OSCC leads the patient to a forced mutism sometimes preceded by poor verbal communication. Although initially described in the context of psychosomatic illnesses, alexithymic characteristics may be observed in patients with a wide range of medical and psychiatric disorders (Sifneos, Nemiah, 1973, cited by Marty, 1995).

\subsubsection{Traumatic episodes}

The existence of events that greatly disturbed the patients' emotional lives may be interpreted as cumulative trauma. The clinical records of such patients reveal episodes of labour dissatisfaction, overadjustment to extreme labour conditions, submission, unquestioned acceptance of social position, tragic loss of close relatives, change of roles or loss of working status.

\subsubsection{Vulnerability}

OSCC patients are vulnerable since the lesion is associated with unhealthy habits like alcoholism and tobacco addiction. Such habits are sometimes disruptive behaviours that appear as a consequence of unresolved affective problems. Bodily vulnerability (Zukerfeld, R. 1999, 2005) is defined as the possibility of either dysfunctional somatic behaviours and reactions to adverse, stressing factors or to cumulative trauma. 


\subsection{Emotional state during treatment}

Treatment shocks the OC patients in a global way, affecting their quality of life. They have to process a great deal of endogenous and exogenous stimuli. When the treatment is indicated, the first struggle is required: the patients have to adapt to a new routine, thus altering their usual habits; they have to accept new schedules and new premises even when they are far removed from their usual places of residence. The newly established routine increases the patients' dependence since they need the care and attention of other persons as well as having to take care of themselves. Side effects produced by irradiation in the oral cavity make tasting, chewing and swallowing difficult. These impairments lead to loss of appetite and loss of weight, all of which tend to unbalance their emotional state. Gaining weight becomes a major worry for the patients and their families. In some cases, the restrained, underlying anguish that has dominated the patient's life finds a way out in the disease itself. That chronic state of dejection has been described in systemic patients as hidden depression, devoid of complaints or whining (Marty, 1966).

\subsection{Interdisciplinary approach}

In 2010, a partly structured, written survey was carried out. It was addressed to individual patients and to those acting as their companions who attended the Oncology Service at Hospital Nacional de Clínicas with the aim of finding out their opinion about the interdisciplinary care they were receiving. They were questioned about: Overall service performance (favourable or unfavourable), presence of several health professionals during consultation, patient's suggestions to improve the service, optional therapies they would like to receive. The interviewed patients had been in contact with the service for a minimum of 3 months and a maximum of 6 years. Results: $53 \%$ of interviewed were male; $59 \%$ were smokers, $41 \%$ drank alcohol, $42 \%$ consumed both alcohol and tobacco. The $88 \%$ were satisfied, using the option "favourable" to describe their opinion about the service. They regarded the presence of dentists and psychologists in the team as very valuable; $71 \%$ declared they ignored the profession of the people present at consultation and $59 \%$ stated they preferred to be seen by several professionals. Concerning the medical services they would like to be offered, their preference rates were: social work (25\%), physiotheraphy and language theraphy (18\% each one) and personalized psychotherapy $12 \%$. The following conclusions were drawn from the aforementioned results: the interdisciplinary team appears as a recommended approach for OC patients, not only because it focuses the disease comprehensively but also because the patients themselves expressed a positive point of view in its regard. Although the interdisciplinary approach to cancer patients is established in health systems, it is important to know how good this model works from the patient's viewpoint.

- The dynamics of consultation is mainly based on a unilateral information medical request, being the patient's role fairly secondary. Most patients did not know the specialty of the professionals present at consultation.

The patient plays a leading role both in defining and privileging his health problems and in accepting or refusing the possible solutions. Helping the patient to become active and to regain control of his own life is a desirable aim in every medical case. However, when dealing with OC patients, this goal acquires a special dimension. 


\subsection{The role of the psychologist}

Psycho oncology conceives cancer as a symptom of an illness comprising myriads of factors both at its starting point, during its course and in its recovery stage (Middleton, 2002). As a field of knowledge, psycho oncology goes beyond the limits of disciplinary knowledge. The role of the psychologist in the OC team may be summarized as follows:

- $\quad$ Pave the way for a more interactive consultation by stimulating the patient's participation in such a way that communication can flow more easily among patient, relatives and medical team.

- $\quad$ Ask for and provide information.

- Bring into consultation aspects related with the patient's lifestyle : food, sleeping habits, leisure time, side effects of the treatment.

- Lower the patient's depersonalization caused by their illness and its demanding attention.

- Propose the patient to make a critical reflection about the association between his lifestyle and his illness.

- Assign due importance to the role of their companions and to their supporting net of relations. Encourage, support, challenge the patient and their family.

- Contribute to install the idea that the illness should be perceived as a meaningful experience, as a chance for reflection and change.

- Understand the incidence of psycho social factors during the course of the illness.

As a member of the medical team dealing with OC patients, the psycho oncologist acts as a catalyst. His presence helps the patients' psychological state, which may contribute to a better understanding of their reality.

\section{Conclusion}

OSCC has a bad prognosis and survival time is short in spite of the technological advances applied to treatments.

Most patients, disregarding the initial symptoms, go to consultation at advanced OSCC stages. Pre-malignant lesions may appear 10 years before the initial OSCC manifestations. Although the carcinoma may be preventable through treatment of pre-cancerous lesions, many dentists and family physicians are not performing the opportunistic oral cavity exams. Oral cavity cancers can be detected easily with a simple oral examination, but compared to cancers that involve more elaborate screening tests (i.e., breast, prostate and colon), the rate of early diagnosis has not improved over time.

OSCC is related to preventable risk factors. Therefore, we strongly advocate that doctors should discourage all their patients from smoking and drinking excessively. Furthermore, intensive public promotion and educational campaigns are imperative to increase patient awareness.

Dental professionals have an important role both in primary prevention of oral cancer -by inducing healthy life styles- and in secondary prevention by detecting oral cancer or its precursor lesions at early stages.

\section{Acknowledgment}

We want to express our gratitude to our teachers Dr Hector Lanfranchi, Dr Julio Diaz and Dr David Grinspan, and to all B Stomatology Service members for their unfailing support and cooperation. 
Our thanks to Julia for her work as translator and proof-reader.

We thank the Science and Technology Secretary (SeCyT) and the National University of Cordoba (UNC) for their financial support.

\section{References}

Aitasalo, K., Grenman, R., Virolaine, E., Niinikoski, J. \& Klossner, J. (1995). A modified protocol to treat early osteoradionecrosis of the mandible. Undersea Hyperb Med, Vol 22, No2, pp.(161-70), ISSN: 1066-2936

Allison, P., Franco, E. \& Feine, J. (1998). Predictors of professional diagnostic delay for upper aerodigestive tract carcinoma. Oral Oncol, Vol 34, pp. (127-32). ISSN: 1368-8375

Barker, G., Barker, B. \& Gier, R. (1996). Oral management of the cancer patient: A guide for the health professional. Kansas City, MO: University of Missouri - Kansas City.

Bellm, L., Epstein J., Rose-Ped, A., Aitasalo, K., Grenman, R., Virolaine, E., Niinikoski, J. \& Klossner, J. (1995). A modified protocol to treat early osteoradionecrosis of the mandible. Undersea Hyperb Med 1995; Vol 22, No2, pp. (161-70). ISSN: 1066-2936

Bolesina, N., Morelatto, R., Belardinelli, P., Fernández, E., Herrera, G., López de Blanc, S. (2007) http://iadr.confex.com/iadr/arg07/preliminaryprogram/abstract_114584.htm, ISSN: 0022-0345

Boring, C., Squires, T. \& Tong, T. (1994). Cancer Statistics. Cancer J Clin, Vol 44, pp. (7-26). ISSN: 1432-1335

Boyle, P., Autier, P. \& Bartelink, H. et al. (2003). European code against cancer and scientific justification: third version. Ann Oncol, Vol. 14, No7, pp. (973-1005). ISSN: 0923-7534

Boudewijn, J., Braakhuis, A., Otto Visser, C. \& René Leemans, A. (2009). Oral and oropharyngeal cancer in The Netherlands between 1989 and 2006: Increasing incidence, but not in young adults. Oral Oncol, Vol 45, No e85, pp. (89-87). ISSN: 1368-8375

Brandizzi, D., Gandolfo, M., Velazco, M., Cabrini, R. \& Lanfranchi, H. (2008). Clinical features and evolution of oral cancer: A study of 274 cases in Buenos Aires, Argentina. Med Oral Patol Oral Cir Bucal, Vol Sep1, No13 (9), pp.(E544-8), ISSN 1698-6946.

Brohua, X., Tromp, D., Horijk, G., Winnubst, J. \& De Leew, R. (2005). Role of alcohol and smoking in diagnostic delay of head and neck cancer patients. Acta Otolaryngol, Vol. 125, No. 5, (May), pp. (552-556). ISSN: 0001-6489

Brohua, X., Tromp, D., Koole, R., Hordijk, G., Winnbust, J. \& De Leeuw, J. (2007). Professional delay in head and neck cancer patients: analysis of the diagnostic pathway. Oral Oncol, Vol.43, pp. (551-556). ISSN: 1368-8375

Browman, G., Wong, G., Hodson, I., Sathya J., Russell, R. \& McAlpine, L., et al. (1993) Influence of cigarette smoking on the efficacy of radiation therapy in head and neck cancer. New Eng J Med. Vol.328, pp. (159-163). ISSN: 0028-4793

Brown, L., Dreizen, S. \& Handler, S., et al. (1975). The Effects of Radiation Induced Xerostomia on Human Oral Microflora. J Dent Res,Vol. 54, No. 4, pp. (740-750). ISSN: 0022-0345

Carl W. \& Schaff N. (1974). Dental Care for the Cancer Patient. J Surg Oncol, Vol. 6, No. 4, pp. (293-310). ISSN: 1096-9098 
Chandu A., G. Adams, A. C. H. Smith. (2005). Factors affecting survival in patients with oral cancer: an Australian perspective. Int. J. Oral Maxillofac. Surg., Vol. 34, pp. (514-520). ISSN: 0901-5027

Daly, T. \& Drane, J. (1972). Management of Dental Problems in Irradiated Patients. University of Texas Press, Houston, Texas.

Dimitroulis, G., Reade, P. \& Wiesenfeld, D. (1992). Referral patterns of patients with oral squamous cell carcinoma, Australia. Eur J Cancer B Oral Oncol, Vol 28B, pp. (23-7). ISSN: 0964-1955

Elwood, J. \& Gallagher, R. (1985). Factors influencing early diagnosis of cancer of the oral cavity. CMAJ, Vol 133, pp. (651-6). ISSN: 1488-2329

Epstein, J., Chin, E., Jacobson, J., Rishiraj, B. \& Le N. (1998). The relationship among fluoride, cariogenic oral flora, and salivary flow rate during radiation therapy. Oral Surg Oral Med Oral Pathol Oral Radiol Endod; Vol. 86, No. 3, pp. (286-292). ISSN: 10792104

Ferlay, J., Shin, H., Bray, F., Forman, D., Mathers, C. \& Parkin, D. (2010). Estimates of worldwide burden of cancer in 2008: GLOBOCAN 2008. International Journal of Cancer, 127, 12, 15 (Dec 2010), pp. (2893-2917). ISSN: 1097-0215

Gao, W. \& Guo, C. (2009). Factors related to delay in diagnosis of oral squamous cell carcinoma. J Oral Maxillofac Surg, Vol 67, pp. (1015-1020). ISSN 0278-2391

Gorsky, M. \& Dayan, D. (1995). Referral delay in diagnosis of oro/oropharyngeal cancer in Israel. Eur J Cancer B Oral Oncol, Vol 31B, pp. (166-8). ISSN: 0964-1955

Grinspan, D. (1983). Enfermedades de la Boca. Tomo V. Editorial Mundi S.A.I.C.y F., ISBN: 950-545-010-9, Buenos Aires Argentina.

Hindle, M., Downer, D., Moles D. \& Speight P. (2000). Is alcohol responsible for more intraoral cancer? Oral Oncol Vol 36, pp. (328-333). ISSN: 1368-8375

Hinds E. (1971). Dental Care and Oral Hygiene Before and After Treatment. Radiation Caries. J Am. Med Assoc, Vol 215, pp. (964-6). ISSN: 1538-3598.

Humphris, G., Freeman R. \& Clarke H. (2004). Risk perception of oral cancer in smokers attending primary care: a randomized controlled trial. Oral Oncol. Vol. 40, No. 9, pp. (916-924). ISSN: 1368-8375

Jansma, J., Vissink, A., Gravenmade, E., Visch L., Fidler V. \& Retief D. (1989). In vivo study on the prevention of post-radiation caries. Caries Res, Vol 23, pp. (172-178). ISSN: 0008-6568

Jansma, J., Vissink, A. \& Jongebloed, W., Retief, D., Johannes's-Gravenmade, E. (1993). Natural and induced radiation caries: a SEM study. Am J Dent, No. 6, pp. 130-136. ISSN: 0894-8275

Jongebloed, W., Gravenmade, E. \& Retief, D. (1988). Radiation caries. A review and SEM study. Am J Dent Vol. 1, pp. (139-146).ISSN: 0894-8275

Jovanovic, A., Kostense, P., Schulten, E., Snow G. \& Van Der Waal, I. (1992). Delay in diagnosis of oral squamous cell carcinoma; a report from the Netherlands. Eur J Cancer B Oral Oncol, 28B, pp. (37-8). ISSN: 0964-1955

Jovanovic, A., Schulten, E. \& Kostense, P. et al. (1993). Tobacco and alcohol related to the anatomical site of oral squamous cell carcinoma. J Oral Pathol Med, Vol 22, pp. (459-462). ISSN: 0904-2512 
Kerdpon, D. \& Sriplung, H. (2001).Factors related to delay in delay in diagnosis of oral squamous cell carcinoma in southern Thailand. Oral Oncol, Vol. 37, No. 2, (Feb), pp. (127-31). ISSN: 1368-8375

Khoo, S., Shanmuhasuntharam, P., Mahadzir, W., Tay, K., Latif, A. \& Nair, S. (1998). Factors involved in the diagnosis of oral squamous cell carcinoma in Malaysia. Asia Pac J Public Health, Vol 10, pp. (49-51). ISSN: 1010-5395.

Kowalski, L., Franco, E. \& Torloni, H., et al. (1994). Lateness of diagnosis of oral and oropharyngeal carcinoma: factors related to the tumour, the patient and health professionals. Eur J Cancer B Oral Oncol.; No. 30B, pp: (167-173). ISSN: 0964-1955

Kowalski, L. \& Carvalho, A. (2001). Influence of time delay and clinical upstaging in the prognosis of head and neck cancer. Oral Oncol, Vol. 37, No. 1, pp. (94-98). ISSN: 1368-8375

Liu, L., Kumar S., Sedghizadeh P., Jayacar A., \& Shuler C. (2008). Oral squamous cell carcinoma incidence by subsite among diverse racial and ethnic populations in California. Oral Surg Oral Med Oral Pathol Oral Radiol Endod, Vol 105, pp.470-80. ISSN:1079-2104

López Castaño, F., Oñate Sánchez, R., Roldán Chicano, R. \& Cabrerizo Merino, M. (2005). Revisión Measurement of secondary mucositis to oncohematologic treatment by means of different scale. Med Oral Patol Oral Cir Bucal, Vol.10, pp. (412-21). ISSN: 1698-4447.

Marty, P. (1995). La psicosomática del adulto, 2do Edición, Amorrortu, ISBN: 950-518-523-5, Buenos Aires.

Mashberg, A., Merletti, F., Boffetta, P., Gandolfo, S., Ozzello, F., Fracchia, F. \& Terracini, B. (1989). Appearance, site of occurrence, and physical and clinical characteristics of oral carcinoma in Torino, Italy. Cancer, Vol 63, pp. (2522-7). ISSN: 1097-0142.

McKenzie, M., Wong, F., Epstein, J. \& Lepawsky, M. (1993). Hyperbaric oxygen and postradiation osteonecrosis of the mandible. Eur J Cancer B Oral Oncol, Vol 29B, No 3, pp. (201-7). ISSN: 0964-1955.

Middleton, J. (2002). Psico-oncología en el siglo XXI, en Revista Actualidad Psicológica $N^{\circ} 298$, Clínica de Pacientes con cáncer, pp. (30-32). ISSN 0325-2590

Morelatto, R., Herrera, M., Fernández, E., Corball A., López de Blanc S. (2007). Diagnostic delay of oral squamous cell carcinoma in two diagnosis centers in Córdoba Argentina. J Oral Pathol , 36 (7) pp (405-08). ISSN: 0904-2512.

Neville, B., Damm, D. \& Allen, C. et al. (2002). Oral \& Maxillofacial Pathology. 2nd ed. Phila., PA: Saunders, pp. (337-369).

Neville, B. \& Day, T. (2002). Oral cancer and precancerous lesions. CA - A Cancer J Clin, No 52, pp. (195-215). ISSN: 1542-4863

Olmos, M. 2010, Evaluación de un servicio público de atención de cáncer de cabeza y cuello. 5to Congreso Multidisciplinario de Salud Comunitaria del Mercosur, San Luis, Argentina, set. 2010.

Onizawa, K., Nishihara, K., Yamagata, K., Yusa, H., Yanagawa, T. \& Yoshida, H. (2003). Factors associated with diagnostic delay of oral squamous cell carcinoma. Oral Oncol, Vol 39, pp. (781-8). ISSN: 1368-8375

O'Sullivan E. (2001). Some insights into the potential for the earlier detection of oral cancer: A population-based study. In: Seventh International Congress on Oral Cancer, April 2001, The Hague, Netherlands. Oral Oncol, Vol 37, pp. (553). ISSN: 1368-8375 
Parkin, D., Bray, F., Ferlay, J. \& Pisani, P. (2005). Global cancer statistics, 2002. CA-A Cancer J Clin, Vol.55, pp. (74-108). ISSN: 1542-4863

Pinholt, E., Rindum, J. \& Pindborg, J. (1997). Oral cancer: a retrospective study of 100 Danish cases. Br J Oral Maxillofac Surg, Vol. 35, pp. (77-80). ISSN: 0266-4356

Pitiphat, W., Diehl, S., Laskaris, G., Carstsos, V., Douglass, C. \& Zavras, A. (2002). Factors associated with delay in the diagnosis of oral cancer. J Dent Res, Vol. 81, pp. (192197). ISSN: 0022-0345

Ramirez-Amador, V., Silverman, S. Jr, Mayer, P., Tyler, M. \& Quivey, J. (1997). Candidal colonization and oral candidiasis in patients undergoing oral and pharyngeal radiation therapy. Oral Surg Oral Med Oral Path Oral Radiol Endod; Vol. 84, No. 2, pp. (149-153). ISSN: 1079-2104.

Robledo, G., Belardinelli, P., Herrera, C., Criscuolo, I., López de Blanc, S. (2008). Level of Public Awareness about Oral Cancer in Cordoba, Argentina. Rev Claves en Odontología 2008, Vol. 15, Nº1: pp. (23-30). ISSN: 1666-0706.

Rogers, S., Pabla, R., Mc Sorley, A. Lowe, D., Brown, J. \& Vaughan, E. (2007). An assessment of deprivation as a factor in the delay presentation, diagnosis and treatment in patients with oral and oropharyngeal squamous cell carcinoma. Oral Oncol, Vol. 43, pp. (649). ISSN: 1368-8375

Sargeran, K., Murtomaa, H., Safavi, SM., Vehkalahti, MM., Teronen, O. (2008). Survival after diagnosis of cancer of the oral cavity. Br J Oral Maxillofac Surg, Vol. 46, 3, pp. (187-191). ISSN:0266-4356.

Scully C. and Felix D. (2006). Oral Medicine - Update for the dental practitioner Oral cáncer. Br Dent J, Vol. 200, N 1, pp 13-17. ISSN: 007-0610

Schávelszon, J. 2002. La psico-oncología en el tratamiento del cáncer, en Revista Actualidad Psicológica. $N^{\circ}$ 298, Clínica de Pacientes con cáncer, 9-11. ISSN: 0325-2590, Buenos Aires.

Shah, J., Candela, F. \& Poddar, A. (1990). The patterns of cervical lymph node metastasis from squamous carcinoma of the oral cavity. Cancer, Vol 66, pp. (109-113). ISSN: 1097-0142

Shah, J. \& Lydiatt, W. (1995). Treatment of cancer of the head and neck. CA Cancer J Clin, No. 45, pp. (352-368). ISSN: 1542-4863

Shaw H. (1997). The British Association of Head and Neck Oncologists within the wider perspectives of the USA and Europe. Ann R Coll Surg Engl, Vol May, No 79 (3 Suppl), pp. (111-4). ISSN: 0035-8843

Silverman, S. Jr, Dillon, W. \& Fischbein, N. (1998). Diagnosis In: Silverman S. Jr ed. Oral Cancer. 4th ed. Hamilton, Ontario, Canada: BC Decker Inc, pp. (41-66).

Soderholm A. (1990). Oral carcinoma of the mandibular region. Br J Oral Maxillofac Surg, Vol 28, pp. (383-9). ISSN: 0266-4356

Sonis, S., Eilers, J., Epstein J., LeVeque, F., Liggett, W. Jr. \& Mulagha, M.T., et al. (1999). Validation of a new scoring system for the assessment of clinical trial research of oral mucositis induced by radiation or chemotherapy. Mucositis Study Group. Cancer No. 85, pp. 2103-2113.

Stevens M.H., Gardner J.W., Parkin J.L. \& Johnson L.P. (1983). Head and neck cancer survival and life-style change. Arch Otolaryngol. No.109, pp. 476-479. ISSN: 08864470 
Stone R., Potting C.M.J., Clare S., Uhlenhopp M., Davies M., Mank A. \& Quinn B. (2007). Management of oral mucositis at European transplantation centers. European Journal of Oncology Nursing, Vol 11, pp. S3-S9. ISSN: 1462-3889

Stone, R., Potting, C., Clare, S., Uhlenhopp, M., Davies, M., Mank, A. \& Quinn, B. (2007). Management of oral mucositis at European transplantation centres. European Journal of Oncology Nursing, Vol 11, pp. (S3-S9). ISSN: 1462-3889

Sznajder, A., 2006 Posgrado en Salud Social y Comunitaria- Programa Médicos ComunitariosMódulo 8 Trabajo en Equipo en Salud- Plan Federal de Salud- Ministerio de Salud y Ambiente de la Nación Argentina, ISBN 950-38-0035-8. Buenos Aires.

Toljanic J., Heshmati R. \& Bedard J. (2002). Dental follow-up compliance in a population of irradiated head and neck cancer patients. Oral Surg Oral Med Oral Pathol Oral Radiol \& Endod, Vol 93, No 1, pp. 35-8. ISSN: 1079-2104.

Tromp D., Brouha X., Hordijk G., Winnubst J. \& De Leeuw R. (2005). Patient and tumor factors associated with advanced carcinomas of the head and neck. Oral Oncol, Vol 41, pp. 313-9. ISSN: 1368-8375

Vendrell Rankin K. \& Daniel L. (1999). Oral Health in cancer Therapy. A guide for health care professionals, Texas Cancer Council.

Vissink A., Jansma J., Spijkervet F., Burlage F. \& Coppes R. (2003). Oral sequelae of head and neck radiotherapy. Crit Rev Oral Biol Med,Vol 14, pp. 199-212. ISSN: 1045-4411

Vora H., Shah N., Patel D., Trivedi T. \& Chikhlikar P. (2003). Prognostic significance of biomarkers in squamous cell carcinoma of the tongue: multivariate analysis. J Surg Oncol. No. 82, pp. 34-50. ISSN: 1096-9098.

Walker, M., Williams K. \& Wichman B. (2008). Post-radiation dental index: development and reliability. Support Care Cancer No. 16, pp. 525-530. ISSN: 1433-7339

Warnakulasuriya, K., Robinson, D. \& Evans, H. (2003). Multiple primary tumours following head and neck cancer in southern England during 1961-1998. J Oral Pathol Med. No. 32, pp. 443-449. ISSN: 0904-2512

Warnakulasuriya, S., Mak, V, Moller, H. (2007) Oral cancer survival in young people in South East England. Oral Oncol, 43 pp982-986. ISSN: 1368-8375

West, R., Alkhatib, M., McNeill, A. \& Bedi, R. (2006). Awareness of mouth cancer in Great Britain. Br Dent J No.,200, pp. 167-169. ISSN: 0007-0610.

Wildt, J., Bundgaard, T. \& Bentzen, S. (1995). Delay in the diagnosis of oral squamous cell carcinoma. Clin Otolaryngol Allied Sci, Vol 20, pp. 21-5. ISSN: 0307-7772

World Health Organization. (1979). Handbook for reporting results of cancer treatment. WHO Offset Publications. Vol. 48. World Health Organization, Geneva, Switzerland, pp. 15-22.

Zukerfeld, R.-Zukerfeld, R. (1999). Psicoanálisis tercera tópica y vulnerabilidad somática, Lugar Editorial, ISBN 959-892-077-7, Buenos Aires.

Zukerfeld, R.-Zukerfeld, R. (2005). Procesos Terciarios, de la vulnerabilidad a la resiliencia, Lugar Editorial, ISBN 950-892-245-1, Buenos Aires. 


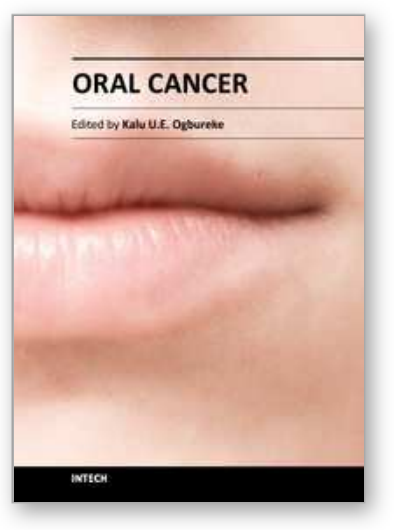

\author{
Oral Cancer \\ Edited by Dr. Kalu U. E. Ogbureke
}

ISBN 978-953-51-0228-1

Hard cover, 388 pages

Publisher InTech

Published online 14, March, 2012

Published in print edition March, 2012

Oral cancer is a significant public health challenge globally. Although the oral cavity is easily accessible, early diagnosis remains slow compared to the enhanced detection of cancers of the breast, colon, prostate, and melanoma. As a result, the mortality rate from oral cancer for the past four decades has remained high at over $50 \%$ in spite of advances in treatment modalities. This contrasts with considerable decrease in mortality rates for cancers of the breast, colon, prostate, and melanoma during the same period. This book attempts to provide a reference-friendly update on the etiologic/risk factors, current clinical diagnostic tools, management philosophies, molecular biomarkers, and progression indicators of oral cancer.

\title{
How to reference
}

In order to correctly reference this scholarly work, feel free to copy and paste the following:

Nicolás Bolesina, Fabián L. Femopase, Silvia A. López de Blanc, Rosana A. Morelatto and María Alicia Olmos (2012). Oral Squamous Cell Carcinoma Clinical Aspects, Oral Cancer, Dr. Kalu U. E. Ogbureke (Ed.), ISBN: 978-953-51-0228-1, InTech, Available from: http://www.intechopen.com/books/oral-cancer/oral-squamouscell-carcinoma-clinical-aspects

\section{INTECH}

open science | open minds

\section{InTech Europe}

University Campus STeP Ri Slavka Krautzeka 83/A 51000 Rijeka, Croatia Phone: +385 (51) 770447

Fax: +385 (51) 686166 www.intechopen.com

\section{InTech China}

Unit 405, Office Block, Hotel Equatorial Shanghai No.65, Yan An Road (West), Shanghai, 200040, China 中国上海市延安西路65号上海国际贵都大饭店办公楼405单元 Phone: +86-21-62489820

Fax: $+86-21-62489821$ 
(C) 2012 The Author(s). Licensee IntechOpen. This is an open access article distributed under the terms of the Creative Commons Attribution 3.0 License, which permits unrestricted use, distribution, and reproduction in any medium, provided the original work is properly cited. 